\title{
Histological and Histomorphometric Effectiveness of the Barrier Membranes for Jawbone Regeneration: An Overview of More Than 30 Years' Experience of Research Results of the Italian Implant Retrieval Center (1988-2020)
}

\author{
Margherita Tumedei ${ }^{1}$ (D) , Carlos Fernando Mourão ${ }^{2,+}\left(\mathbb{D}\right.$, Silvia $^{\prime}$ Agostino $^{1,+}\left(\mathbb{D}\right.$, Marco Dolci $^{1}$ (D), \\ Michele Di Cosola ${ }^{3,4}$, Adriano Piattelli ${ }^{1,5,6, *}$ and Alessandra Lucchese ${ }^{7,8,9}$ (D)
}

1 Department of Medical, Oral and Biotechnological Sciences, University “G. D'Annunzio" of Chieti-Pescara, 66100 Chieti, Italy; margytumedei@yahoo.it (M.T.); silviadagostino00@gmail.com (S.D.); marco.dolci@unich.it (M.D.)

2 Department of Oral Surgery, Dentistry School, Fluminense Federal University, Rio de Janeiro 20000, Brazil; mouraoufrj@yahoo.com.br

3 Department of Clinical and Experimental Medicine, Riuniti University Hospital of Foggia, Viale Luigi Pinto 1, 71122 Foggia, Italy; dr.dicosola@gmail.com

4 Private Practice, Via Acquaviva, 4, Ruvo di Puglia, 70037 Bari, Italy

check for updates

Citation: Tumedei, M.; Mourão, C.F.; D’Agostino, S.; Dolci, M.; Di Cosola, M.; Piattelli, A.; Lucchese, A. Histological and Histomorphometric Effectiveness of the Barrier Membranes for Jawbone

Regeneration: An Overview of More Than 30 Years' Experience of Research Results of the Italian Implant Retrieval Center (1988-2020). Appl. Sci. 2021, 11, 2438. https:// doi.org/10.3390/app11052438

Academic Editor: Giuseppe Perale

Received: 9 February 2021

Accepted: 4 March 2021

Published: 9 March 2021

Publisher's Note: MDPI stays neutral with regard to jurisdictional claims in published maps and institutional affiliations.

Copyright: (c) 2021 by the authors. Licensee MDPI, Basel, Switzerland. This article is an open access article distributed under the terms and conditions of the Creative Commons Attribution (CC BY) license (https:// creativecommons.org/licenses/by/ $4.0 /)$.
5 Biomaterials Engineering, Catholic University of San Antonio de Murcia (UCAM), Av. de los Jerónimos, Guadalupe, 13530107 Murcia, Spain

6 Fondazione Villaserena per la Ricerca, Città Sant'Angelo, 65121 Pescara, Italy

7 Unit of Orthodontics, Division of Dentistry IRCCS San Raffaele Scientific Institute, 20132 Milan, Italy; lucchese.alessandra@unisr.it

8 Unit of Orthodontics, School of Dentistry, Vita-Salute San Raffaele University, 20132 Milan, Italy

9 Unit of Dentistry, Research Center for Oral Pathology and Implantology, IRCCS San Raffaele Scientific Institute, 20132 Milan, Italy

* Correspondence: apiattelli@unich.it; Tel.: +39-0871-3554083

+ These authors had an equal contribution to the study.

\begin{abstract}
With the advent of implant dentistry, height and width of the bone site are fundamental to perform implant placements. There are several techniques to restore the amount of bone loss and one of them is guided bone regeneration, which is based on the employment of a membrane in order to bypass non-osteogenic cell invasion in the bone healing area, dispersing every interference with bone regeneration. Two expert reviewers performed a retrospective evaluation of all scientific papers published by the Implant Retrieval Center Laboratory of University “G. D'Annunzio" of Chieti-Pescara in the last three decades, and they implemented it by also similar conducting research on the main scientific databases, i.e., PubMed, Scopus, and EMBASE. The search was conducted up to December 2020, and a total of 843 articles published by the Implant Retrieval Center Laboratory of University "G.D'Annunzio" of Chieti-Pescara were identified and evaluated. After the application of inclusion and exclusion criteria, a total of 27 manuscripts were included for the qualitative synthesis: 8 animal studies, 17 human studies, and 2 in vitro articles. The present overview shows the importance of translational research for barrier membranes for bone regeneration, and additionally, the need for experts in different fields and research centers to produce high quality data in future research.
\end{abstract}

Keywords: membranes; collagen barriers; scaffold; bone regeneration; research; overview

\section{Introduction}

Implant dentistry has transformed rehabilitation treatments, bringing an enhancement to patients' life quality. A suitable height and width of the bone site are parameters required to perform dental implant placements. There are several techniques to restore the amount of bone loss; for example, the split crest method [1], bone-grafting strategies [2], or guided bone regeneration (GBR). GBR is widely used in oral surgery and implantology. It is based 
on employing a membrane to bypass non-osteogenic cell invasion in the bone healing area, dispersing every bone regeneration interference. Thus, only osteoprogenitor cells can reach the bone defect site [3-5]. According to Bornstein et al., "additional bone augmentation was indicated in more than $50 \%$ of cases" of implant placement, and GBR was the most common technique performed [6].

Indeed, a fundamental aspect of GBR is the membrane used. Membranes' properties are closely connected with their materials and structure. Therefore, ideal features should be biocompatibility, integration capability with native tissues, stopping other cell invasions, keeping space for blood clot organization, easy clinical management, adequate stiffness, and plasticity to withstand the compression of the overlying soft tissue [7-12]. Membranes can be divided into two generations: non-resorbable membranes, mainly polytetrafluoroethylene (PTFE) in its expanded form (e-PTFE); and resorbable membranes, including collagen forms [13-16]. On the one hand, non-resorbable membranes offer the clinician a shaping site chance and a good barrier effect thanks to a metal core; on the other, they have to be suddenly removed if they are exposed before the healing process ends due to bone infection risk, and they also need a second surgery to be excised. Instead, there are resorbable barriers derive from animals. They should reabsorb in a couple of months due to hydrolysis or enzymatic degeneration, so they have a restricted power in stopping epithelial cell invasion and do not provide a space-making effect because they do not have a metal core. However, there is a low infection risk related to unwanted exposure, and they do not need surgery to be removed.

Nevertheless, collagen membranes overcome their lower space-making effect due to the current technique by the addition of a bone graft into the defect to create a scaffold easily colonizable by desired bone cells. Collagen-based membranes can be obtained from human skin, bovine Achilles tendon, porcine skin, and porcine inner organs [17]. This kind of barrier has different degradation times depending on the animal source, and it means that they could be reabsorbed before the optimal tissue maturation period. Several bioengineering methods are recommended to avoid this adverse event; for example, cross-linking with chemical agents such as glutaraldehyde, genipin, 1-Ethyl-3-(3-dimethylaminopropyl) carbodiimide hydrochloride (EDC), or ultraviolet radiation. Despite the collagen stability improvement after chemical treatment, residues of these agents are responsible for inflammation in the site of placement [18].

Another fundamental characteristic of membranes is the porosity of the structure. It is suggested that the pore size directly influences bone regeneration capability. With that, a better occlusivity towards soft tissue cells can be ensured [19].

Membrane properties are so crucial that the third generation with biologically active components is under development, such as a delivery medium for growth factors and antibiotic molecules [20]. The present study aimed to investigate the membrane's outcomes for bone regeneration procedures in quantitative and qualitative effectiveness during translational evaluations performed Italian Implant Retrieval Center over 30 years.

\section{Materials and Methods}

A retrospective evaluation of all scientific papers published by the Implant Retrieval Center Laboratory of University "G. D'Annunzio" of Chieti-Pescara in the last three decades was performed; it was implemented by also conducting this research on different electronic databases, such as PubMed, Scopus, and EMBASE. The articles screened were limited to papers dealing with membrane applications for bone regeneration. The scientific publications were submitted for qualitative analysis.

\subsection{Inclusion Criteria}

Articles published up to December 2020 were included without language and initial date restrictions. The articles screened were limited only to papers dealing with membrane application for bone regeneration. The scientific publications were submitted for qualitative analysis. According to the search criteria, human studies, in vitro studies, and animal 
model studies were applied to the search paradigm. Articles that did not conform to the inclusion criteria and literature reviews were also excluded from the evaluation.

\subsection{Selection of the Studies}

Data and study selection was performed independently by two expert reviewers (M.T. and A.P.). They used a uniquely designed data-collection form created in the Excel software package (Microsoft Office, Redmond, WA, USA) for the systematic recording of data. In the case of abstracts not being available, the paper's full text was obtained and checked. Literature reviews, case reports, and book chapters were excluded from the qualitative analysis. For excluded articles, a description was included about the reasons for exclusion.

\subsection{Data Extraction}

Data from included articles were extracted and evaluated. The papers were categorized into in vitro assays, animal studies, and human research. The animal and human studies were assessed according to the first author, type of membrane and complex, control sites, research times, and study outcomes.

\section{Results}

\subsection{Papers Selection}

The electronic search procedure is presented in Figure 1. The search was conducted before 20 December 2020, and a total of 843 articles published by the Implant Retrieval Center Laboratory of University "G.D'Annunzio" of Chieti-Pescara were identified and evaluated. A total of 43 literature reviews were excluded from the present investigation, and the full text was analyzed to evaluate the qualitative synthesis eligibility. A total of 770 papers were excluded for the following reasons: topic research $(n=763)$, book chapters $(n=3)$, and case reports $(n=6)$. A total of 27 manuscripts were included for the qualitative synthesis: 8 animal studies $[13,14,21-26], 17$ human studies [13,13,15,16,27-39], and 2 in vitro articles. The in vitro studies evaluated the osteogenic gene expression BMP2, RUNX2 and ALP and the mechanical characteristics of the experimental membranes (Table 1). The histological new bone formation (NBF) represented the most diffused evaluation of the included in vivo studies on animals and humans (Tables 2 and 3).

\subsection{In Vitro Studies}

A total of two studies were performed within in vitro cell cultures [40,41]. Radunovic et al. studied the collagen membranes used to deliver graphene oxide to evaluate multipotent cell populations' differentiation and proliferation [41]. De Marco et al. evaluated graphene oxide/collagen membranes' complex effects on fibroblast cell activity [40].

\subsection{Animal Studies}

A total of six studies were performed on rabbit models: two articles on calvaria defects [22,42], three papers on tibiae defects [23,24,26], and one paper on the knee [43]. Moreover, one article studied dogs' post-extraction defect model [14] and one paper studied calvaria defects on rats [21]. Different typologies of membranes were evaluated: electrically charged Gore-Tex augmentation membranes (GTAM), collagen membranes, polylactic acid derivates, composite polymer-hydroxyapatite membranes, expanded PTFE membranes, Gore-Tex membranes.

\subsection{Human Studies}

A total of five studies were performed associated with implant defects, six articles in the post-extraction alveolar socket, one study on periodontal defects, and five studies on jawbone defects. The follow-up range was from three months to seven years. For all of the studies conducted, histological and histomorphometric assessments on retrieved biopsies were included. 

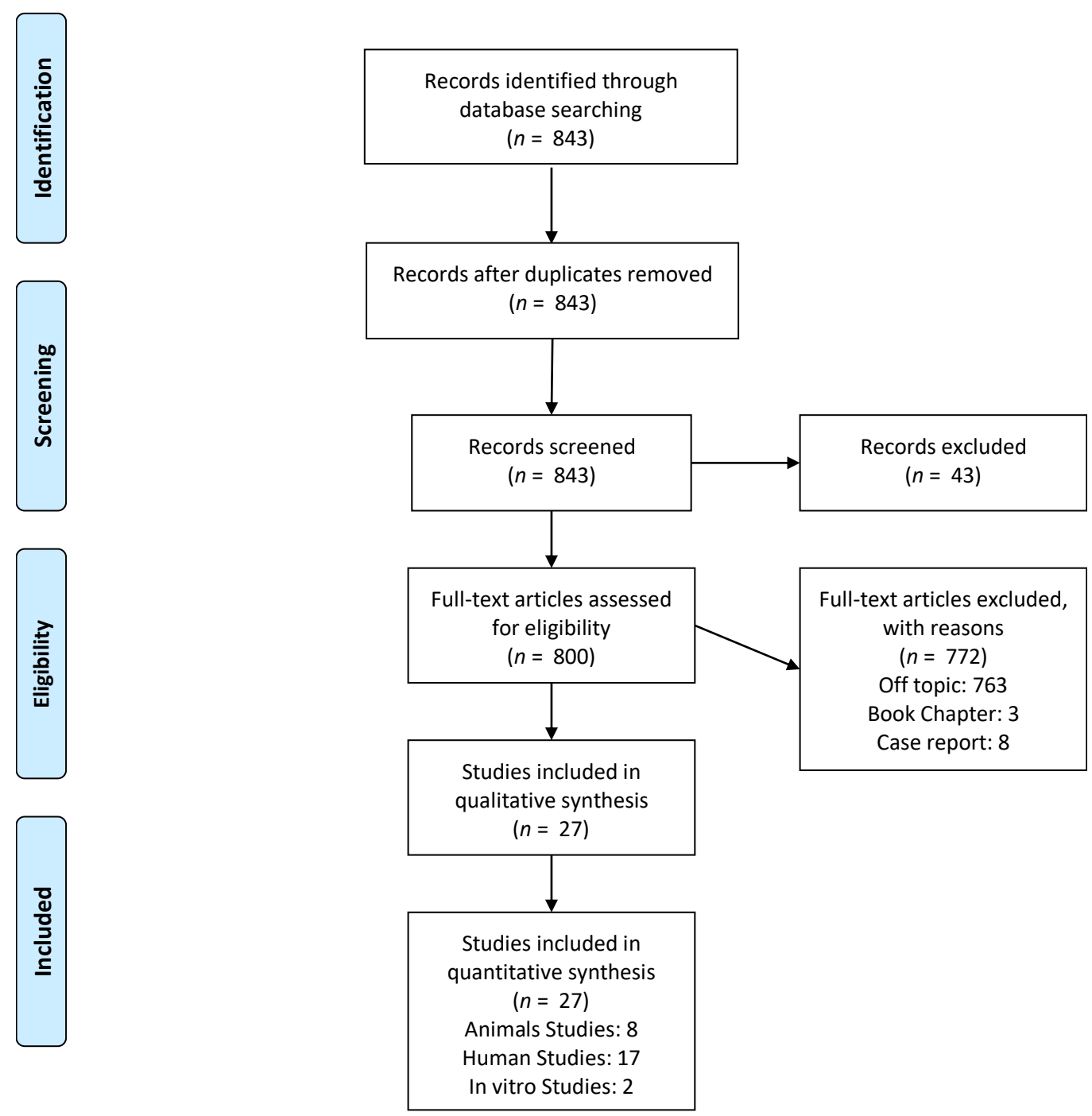

Figure 1. Flow diagram (PRISMA format) of the screening and selection process.

Table 1. Summary of the in vitro studies included for the qualitative analysis

\begin{tabular}{|c|c|c|c|c|c|c|c|c|c|c|}
\hline Authors & Results & Experiment & Ex-Model & $\mathbf{N}$ & Defect & Test & $\mathrm{Ctr}$ & Time & $\begin{array}{l}\text { Membrane } \\
\text { Deforma- } \\
\text { tion }\end{array}$ & Genes \\
\hline $\begin{array}{c}\text { De Marco, } \\
\text { et al. } \\
\text { Biomed. Mat. } \\
2017 \text { [40] }\end{array}$ & $\begin{array}{l}\text { Graphene } \\
\text { oxide } \\
\text { increased the } \\
\text { roughness } \\
\text { and the total } \\
\text { surface } \\
\text { exposed to } \\
\text { the cells }\end{array}$ & $\begin{array}{l}\text { Fibroblast } \\
\text { Activity }\end{array}$ & In Vitro & - & - & $\begin{array}{c}\text { Collagen } \\
\text { Mem- } \\
\text { brane + } \\
\text { Graphene } \\
\text { Fibroblast } \\
\text { Activity } \\
\text { (2 ug vs } \\
10 \text { ug) }\end{array}$ & $\begin{array}{l}\text { Collagen } \\
\text { Mem- } \\
\text { brane }\end{array}$ & $\begin{array}{l}1,3,7 \\
\text { Days }\end{array}$ & \multirow[t]{2}{*}{$\begin{array}{c}\text { Control: } \\
1.9 \pm 0.6 \\
\text { nm Test: } \\
1.4 \pm 0.9 \\
\mathrm{~nm}\end{array}$} & - \\
\hline $\begin{array}{l}\text { Radunovic, } \\
\text { et al. } \\
\text { J. Biomed. } \\
\text { Mater. Res. A. } \\
2017 \text { [41] }\end{array}$ & $\begin{array}{l}\text { Graphene } \\
\text { oxide collagen } \\
\text { membranes } \\
\text { induce the dif- } \\
\text { ferentiation of } \\
\text { dpscs into } \\
\text { osteogenic } \\
\text { cells }\end{array}$ & $\begin{array}{l}\text { Dental } \\
\text { Pulp Stem } \\
\text { Cells } \\
\text { activity }\end{array}$ & In Vitro & - & - & $\begin{array}{c}\text { Graphene } \\
+ \\
\text { Collagen } \\
\text { Mem- } \\
\text { brane + } \\
\text { Dental } \\
\text { Pulp Stem } \\
\text { Cells }\end{array}$ & $\begin{array}{l}\text { Membrane } \\
+ \text { Stem } \\
\text { Cells } \\
\text { Without } \\
\text { Graphene } \\
\text { Oxide }\end{array}$ & $\begin{array}{c}\text { Day } 3,7 \\
14,28\end{array}$ & & $\begin{array}{c}2-10 \\
\mu \mathrm{g} / \mathrm{mL} \\
\mathrm{GO} \\
\text { Increased } \\
\text { expres- } \\
\text { sion of } \\
\text { BMP2, } \\
\text { RUNX2 } \\
\text { and SP7 }\end{array}$ \\
\hline
\end{tabular}


Table 2. Summary of the animal studies included.

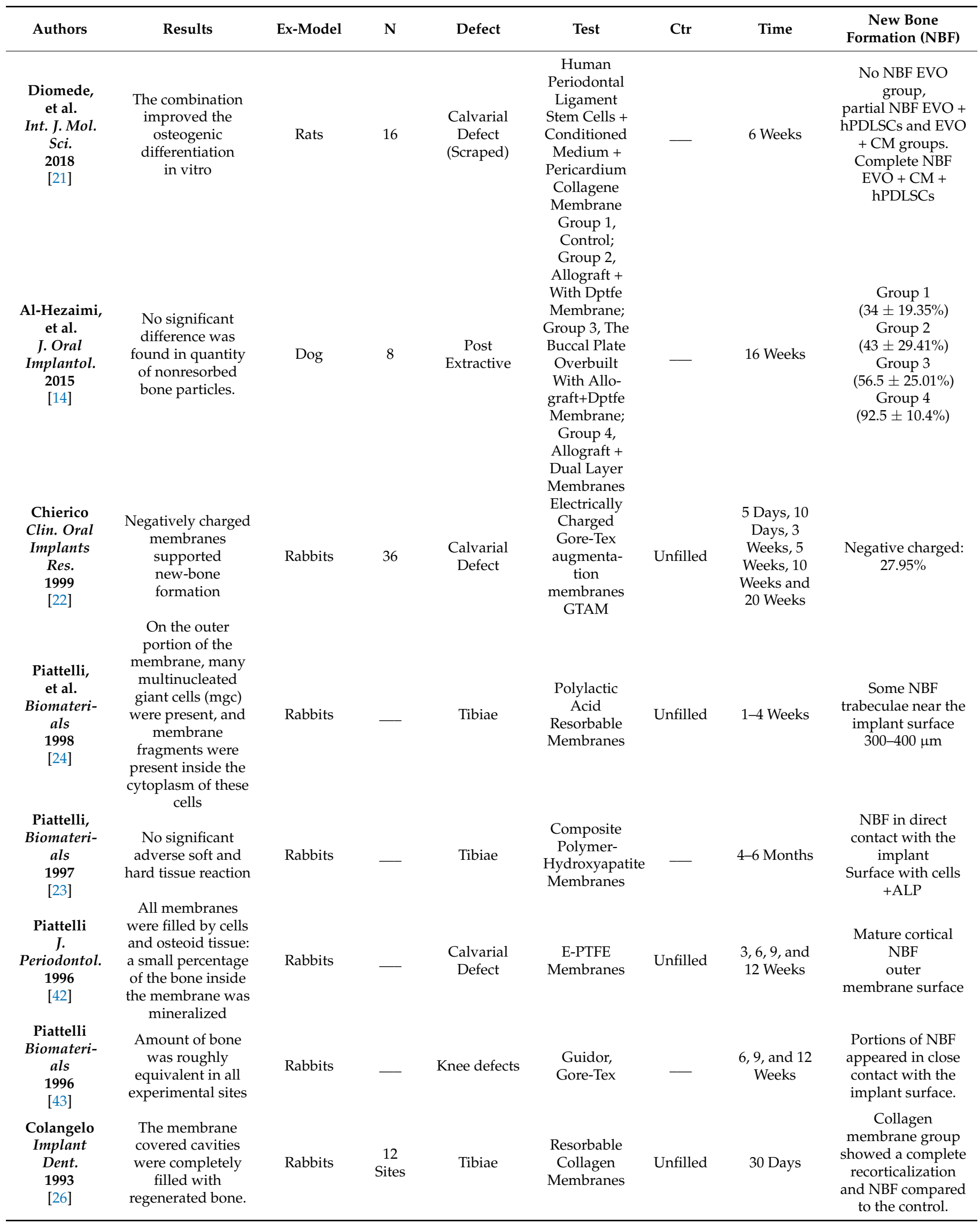


Table 3. Summary of the human studies included.

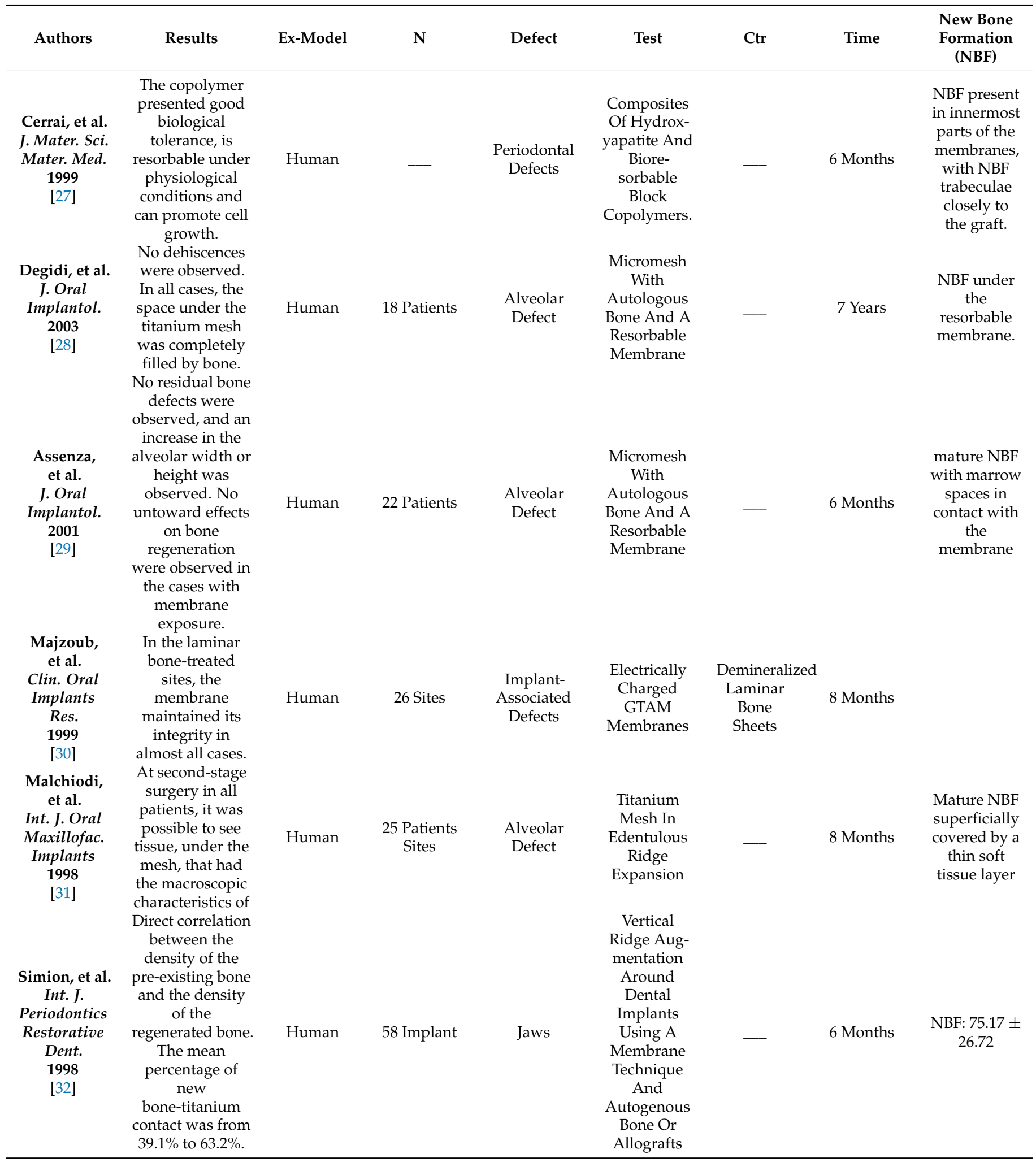


Table 3. Cont

\begin{tabular}{|c|c|c|c|c|c|c|c|c|}
\hline Authors & Results & Ex-Model & $\mathbf{N}$ & Defect & Test & Ctr & Time & $\begin{array}{l}\text { New Bone } \\
\text { Formation } \\
\quad(\mathrm{NBF})\end{array}$ \\
\hline $\begin{array}{l}\text { Simion, et al. } \\
\text { Clin. Oral } \\
\text { Implants } \\
\text { Res. } \\
1997 \\
{[44]}\end{array}$ & $\begin{array}{l}\text { The Pla/Pga } \\
\text { membranes } \\
\text { started to resorb } \\
\text { in the early } \\
\text { stages: this } \\
\text { process } \\
\text { concluded itself } \\
\text { between the 3rd } \\
\text { and } 4 \text { th weeks of } \\
\text { exposure. }\end{array}$ & Human & 8 Device & Lower Jaw & $\begin{array}{l}\text { Pla/Pga } \\
\text { Membrane } \\
\text { Separated } \\
\text { The } \\
\text { Composite } \\
\text { Chambers }\end{array}$ & - & 4 Weeks & - \\
\hline $\begin{array}{l}\text { Simion et al. } \\
\text { Int. J. Oral } \\
\text { Maxillofac. } \\
\text { Implants. } \\
1996 \\
{[15]}\end{array}$ & $\begin{array}{l}\text { Very little or no } \\
\text { bone formation } \\
\text { was detected in } \\
\text { control } \\
\text { specimens. }\end{array}$ & Human & $\begin{array}{l}21 \text { Implant } \\
\text { Defects }\end{array}$ & Lower Jaw & $\begin{array}{c}\text { Seven } \\
\text { Defects Were } \\
\text { Treated With } \\
\text { Pla/Pga } \\
\text { Membranes, } \\
\text { and Five } \\
\text { Were Treated } \\
\text { With E-PTFE } \\
\text { Membranes, } \\
\text { And Four } \\
\text { Were Left }\end{array}$ & $\begin{array}{l}\text { Untreated } \\
\text { (Control } \\
\text { Sites). }\end{array}$ & 6 months & $\begin{array}{c}\text { Higher NBF } \\
\text { in } \\
\text { membranes } \\
\text { is for fresh } \\
\text { extraction } \\
\text { sockets } \\
\text { implants }\end{array}$ \\
\hline $\begin{array}{c}\text { Piattelli } \\
\text { et al. } \\
\text { Biomaterials } \\
1996 \\
{[25]}\end{array}$ & $\begin{array}{l}\text { Defects filled by } \\
\text { a newly formed } \\
\text { tissue with the } \\
\text { macroscopic } \\
\text { features of } \\
\text { mature bone. }\end{array}$ & Human & + & $\begin{array}{l}\text { Alveolar } \\
\text { Defect }\end{array}$ & $\begin{array}{l}\text { Granulate Of } \\
\text { Biphasic } \\
\text { Calcium } \\
\text { Phosphate } \\
\text { Ceramic } \\
\text { (Bcp), E-Ptfe } \\
\text { Membranes }\end{array}$ & - & 6 Months & $\begin{array}{l}\text { In some } \\
\text { regions, the } \\
\text { granules } \\
\text { appearedto } \\
\text { be cemented } \\
\text { by the NFB }\end{array}$ \\
\hline $\begin{array}{c}\text { Piattelli, } \\
\text { et al. } \\
\text { Biomaterials } \\
1996 \\
{[13]}\end{array}$ & $\begin{array}{c}\text { E-PTFE } \\
\text { membranes } \\
\text { showed material } \\
\text { interstices of the } \\
\text { membranes, in } \\
\text { many cases the } \\
\text { presence of } \\
\text { connective tissue } \\
\text { cells and } \\
\text { collagen fibres, } \\
\text { and in two cases } \\
\text { the presence of } \\
\text { bone. } \\
\text { The implant } \\
\text { showed an } \\
\text { angular bony }\end{array}$ & Human & 10 Patients & $\begin{array}{l}\text { Alveolar } \\
\text { Defect }\end{array}$ & $\begin{array}{c}\text { E-PTFE } \\
\text { Membranes }\end{array}$ & - & 6 Months & $\begin{array}{l}\text { The NBF was } \\
\text { locatedin a } \\
\text { central } \\
\text { portion of } \\
\text { E-PTFE } \\
\text { Membranes }\end{array}$ \\
\hline $\begin{array}{l}\text { Simion, et al. } \\
\text { Int. J. } \\
\text { Periodontics } \\
\text { Restorative } \\
\text { Dent. } 1996 \\
\text { [39] }\end{array}$ & $\begin{array}{l}\text { defect at the } \\
\text { smooth collar, } \\
\text { but the } \\
\text { bone-implant, } \\
\text { direct contact } \\
\text { rate seemed, to } \\
\text { be elevated in the } \\
\text { remaining } \\
\text { implant surface. }\end{array}$ & Human & Case Report & $\begin{array}{l}\text { Alveolar } \\
\text { Defect, } \\
\text { Implant } \\
\text { Retrieed }\end{array}$ & $\begin{array}{c}\text { E-PTFE } \\
\text { Membranes } \\
\text { With DFDBA } \\
\text { + Implant }\end{array}$ & - & 4 Years & $\begin{array}{l}\text { Higher NBF } \\
\text { compared to } \\
\text { membranes } \\
\text { alone after } \\
6 \text { months }\end{array}$ \\
\hline $\begin{array}{l}\text { Donath et al. } \\
\text { Eur. J. Oral } \\
\text { Sci. } 1996 \\
{[36]}\end{array}$ & $\begin{array}{l}\text { DFDB with } \\
\text { expanded polyte- } \\
\text { trafluorethylene } \\
\text { (e-PTFE) } \\
\text { membranes. Was } \\
\text { slowly resorbed }\end{array}$ & Human & Case Report & Bone Defects & $\begin{array}{l}\text { Demineralized } \\
\text { Freeze-Dried } \\
\text { Bone In } \\
\text { Conjunction } \\
\text { With E-PTFE } \\
\text { Barrier }\end{array}$ & - & 6 Months & $\begin{array}{l}\text { DFDB } \\
\text { particles } \\
\text { partial } \\
\text { NBF } \\
\text { DFDB no } \\
\text { NBF. }\end{array}$ \\
\hline
\end{tabular}


Table 3. Cont.

\begin{tabular}{|c|c|c|c|c|c|c|c|c|}
\hline Authors & Results & Ex-Model & $\mathbf{N}$ & Defect & Test & Ctr & Time & $\begin{array}{l}\text { New Bone } \\
\text { Formation } \\
\text { (NBF) }\end{array}$ \\
\hline $\begin{array}{l}\text { Piattelli, } \\
\text { et al. } \\
\text { J. Periodon- } \\
\text { tol.1996 } \\
{[35]}\end{array}$ & $\begin{array}{l}\text { The membrane } \\
\text { was filled by a } \\
\text { tissue with the } \\
\text { macroscopic } \\
\text { features of bone, } \\
\text { and the } \\
\text { newly-formed } \\
\text { tissue almost } \\
\text { covered the two } \\
\text { implants. } \\
\text { Histologic } \\
\text { examination } \\
\text { showed that all } \\
\text { retrieved }\end{array}$ & Human & Case Report & $\begin{array}{l}\text { Vertical Aug- } \\
\text { mentation }\end{array}$ & $\begin{array}{l}\text { Resorbable } \\
\text { Freeze-Dried } \\
\text { Dura Mater } \\
\text { Membrane }\end{array}$ & - & 6 Months & $\begin{array}{l}\text { NBF macro- } \\
\text { scopically in } \\
\text { the space } \\
\text { under the } \\
\text { membrane }\end{array}$ \\
\hline $\begin{array}{c}\text { Simion, et al. } \\
\text { Int. J. } \\
\text { Periodontics } \\
\text { Restorative } \\
\text { Dent.1994 } \\
{[37]}\end{array}$ & $\begin{array}{l}\text { miniscrews were } \\
\text { in direct contact } \\
\text { with bone. Histo- } \\
\text { morphometric } \\
\text { analysis of bone } \\
\text { contact gave a } \\
\text { mean value of } \\
42.5+/-3.6 \% \\
\text { for five of the six } \\
\text { examined } \\
\text { miniscrews. }\end{array}$ & Human & $\begin{array}{l}5 \text { Patients, } 15 \\
\text { Sites }\end{array}$ & $\begin{array}{l}\text { Vertical Aug- } \\
\text { mentation } \\
\text { Implant }\end{array}$ & $\begin{array}{c}\text { Membrane } \\
\text { Technique } \\
\text { Associated } \\
\text { With } \\
\text { Osseointe- } \\
\text { grated } \\
\text { Implants }\end{array}$ & - & 6 Months & $\begin{array}{c}\text { NBF of } \\
42.5 \pm 3.6 \%\end{array}$ \\
\hline $\begin{array}{c}\text { Simion, et al. } \\
\text { J. } \\
\text { Periodontol. } \\
1994 \\
{[16]}\end{array}$ & $\begin{array}{l}\text { The study } \\
\text { showed the } \\
\text { possibility that } \\
\text { oral bacteria may } \\
\text { contaminate } \\
\text { eptfe membranes } \\
\text { exposed to the } \\
\text { oral cavity. }\end{array}$ & Human & 5 Sites & $\begin{array}{l}\text { Vertical Aug- } \\
\text { mentation } \\
\text { Implant }\end{array}$ & $\begin{array}{l}\text { Polytetrafluoro- } \\
\text { ethylene } \\
\text { Membrane }\end{array}$ & - & 4 Weeks & $\begin{array}{l}\text { The retrieved } \\
\text { samples } \\
\text { demon- } \\
\text { strated the } \\
\text { presence of } \\
\text { mature NBF } \\
\text { under } \\
\text { Polytetraflu- } \\
\text { oroethylene } \\
\text { Membrane }\end{array}$ \\
\hline $\begin{array}{c}\text { Fontana, } \\
\text { et al. } \\
\text { J. } \\
\text { Periodontol. } \\
1994 \\
{[38]}\end{array}$ & $\begin{array}{l}\text { There was a } \\
\text { partial } \\
\text { dehiscence of the } \\
\text { membrane in } \\
\text { only } 4 \% \text { of the } \\
\text { cases. }\end{array}$ & Human & 69 Patients & $\begin{array}{l}\text { Post- } \\
\text { Extraction } \\
\text { Dental } \\
\text { Implants }\end{array}$ & $\begin{array}{l}\text { Freeze-Dried } \\
\text { Dura Mater }\end{array}$ & - & $\begin{array}{c}3 \text { To } 6 \\
\text { Months }\end{array}$ & $\begin{array}{l}\text { NBF closely } \\
\text { adapted to } \\
\text { the implants }\end{array}$ \\
\hline $\begin{array}{l}\text { Simion, et al. } \\
\text { Int. J. } \\
\text { Periodontics } \\
\text { Restorative } \\
\text { Dent. } \\
1994 \\
{[39]}\end{array}$ & $\begin{array}{l}\text { Guided tissue } \\
\text { regeneration } \\
\text { techniques are } \\
\text { capable of } \\
\text { producing new } \\
\text { bone } \\
\text { osseointegrated } \\
\text { with titanium } \\
\text { dental implants. }\end{array}$ & Human & - & $\begin{array}{l}\text { Post- } \\
\text { Extraction } \\
\text { Sockets }\end{array}$ & $\begin{array}{l}\text { (1) E-PTFE } \\
\text { Membranes } \\
\text { + Autografts, } \\
\text { (2) E-PTFE } \\
\text { Membranes } \\
\text { + DFDB, } \\
\text { (3) E-PTFE } \\
\text { Membranes } \\
\text { + A Deminer- } \\
\text { alized } \\
\text { Allograft } \\
\text { (4) E-PTFE } \\
\text { Membranes } \\
\text { Alone }\end{array}$ & - & 6 Months & $\begin{array}{l}\text { Autogenous } \\
\text { graft } \\
\text { provided the } \\
\text { densest and } \\
\text { the greatest } \\
\text { amount of } \\
\text { NBF. }\end{array}$ \\
\hline
\end{tabular}

\section{Discussion}

The use of membranes in bone regeneration procedures has been validated in the regenerative medicine literature [45-47]. Adopting a barrier to preserve and separate the regenerative compartment from the epithelium compartment is necessary to avoid soft tissue infiltration. This aspect is fundamental to guarantee the blood clot organization, the bone graft's protection, and new bone formation during the healing period $[2,40,48]$. Moreover, the membrane should be histologically characterized with a high level of tol- 
erance by the host tissues, the absence of macrophage infiltrations, and no significant adverse reactions of soft and hard tissues [49-51]. The complete substitution of the membranes' components is one of the significant aspects of entire processes; although using a non-resorbable membrane clinically requires a second stage surgery for its removal, it can create a favorable environment for graft stabilization, vascularization, and osteointegration $[52,53]$. Both in animal and human studies, a higher level of new bone formation was detected in association with different typologies of bone graft $[24,30,42,43,54]$. No evidence of the differences between bone particle resorption patterns was seen with histological analysis [14]. Therefore, in the case of longer follow-ups, earlier mature bone effectiveness was detected in animal studies in association with useful space-maintaining capabilities [23]. Freeze-dried dura mater membrane has been successfully proposed, associated with immediate post-extraction implant positioning [38]. Fontana et al. reported that after six months, in a total of 69 patients treated with an immediate post-extraction implant, there was partial dehiscence of the membrane in a small number of clinical cases $(<4 \%)$ [38]. Chierico et al. reported that negatively charged membranes, on rabbits, could increase the new bone formation in the absence of bone graft materials. The Pla/Pga membrane, after a healing period of four weeks, was histologically still recognizable, and the substitution process continued over six months from the first stage of surgery $[24,33,44]$. The membrane exposure represents critical aspects due to bacteria contamination and oral biofilms adhesion. Simion et al. reported that through scanning electron microscopic and histologic examinations after four weeks of exposure, the bacteria contamination could occur on PTFE membranes [54-56]. Thus, there is a possibility of bone graft disappearance caused by local infection. In the present study, it was possible to observe that translational research is essential to evaluate bone regeneration membrane barriers. After thirty years of studies in the Implant Retrieval Center Laboratory of University "G. D'Annunzio" of Chieti-Pescara, different products have been tested and developed by our research group, all of which produced data from in vitro assays to implants in the surgical bed. All of this is to ensure the biomaterials' quality for the patients.

\section{Conclusions}

Within this overview's limitations, it was possible to demonstrate the importance of translational research for barrier membranes for bone regeneration, which may be used in the surgical bed. With this, the importance of experts in different fields and a research center that produces high quality data for the future implantology and perio-implantology research is fundamental.

Author Contributions: Conceptualization, M.T. and A.P.; methodology, A.P.; software, A.P.; validation, C.F.M.; S.D. and M.D.; formal analysis, A.P.; investigation, A.P.; resources, A.P. and M.T.; data curation, M.D.C. and S.D.; writing—original draft preparation, A.P. and M.T.; writing—review and editing, M.T. and A.L.; visualization, C.F.M.; supervision, M.D.; S.D. and M.D.; project administration, M.T. and A.P. All authors have read and agreed to the published version of the manuscript.

Funding: This research received no external funding.

Institutional Review Board Statement: Not applicable.

Informed Consent Statement: Not applicable.

Data Availability Statement: All experimental data to support the findings of this study are available contacting the corresponding author upon request. The authors have annotated the entire data building process and empirical techniques presented in the paper.

Acknowledgments: The authors declare no acknowledgement for the present research.

Conflicts of Interest: The authors declare no conflict of interest. 


\section{References}

1. Waechter, J.; Leite, F.R.; Nascimento, G.G.; Carmo Filho, L.C.; Faot, F. The Split Crest Technique and Dental Implants: A Systematic Review and Meta-Analysis. Int. J. Oral Maxillofac. Surg. 2017, 46, 116-128. [CrossRef]

2. Chavda, S.; Levin, L. Human Studies of Vertical and Horizontal Alveolar Ridge Augmentation Comparing Different Types of Bone Graft Materials: A Systematic Review. J. Oral Implant. 2018, 44, 74-84. [CrossRef] [PubMed]

3. Chappuis, V.; Rahman, L.; Buser, R.; Janner, S.F.M.; Belser, U.C.; Buser, D. Effectiveness of Contour Augmentation with Guided Bone Regeneration: 10-Year Results. J. Dent. Res. 2018, 97, 266-274. [CrossRef]

4. Çolpak, H.A.; Gönen, Z.B.; Özdamar, S.; Alkan, A.; Kütük, N. Vertical Ridge Augmentation Using Guided Bone Regeneration Procedure and Dental Pulp Derived Mesenchymal Stem Cells with Simultaneous Dental Implant Placement: A Histologic Study in a Sheep Model. J. Stomatol. Oral Maxillofac. Surg. 2019, 120, 216-223. [CrossRef] [PubMed]

5. Comuzzi, L.; Tumedei, M.; Pontes, A.E.; Piattelli, A.; Iezzi, G. Primary Stability of Dental Implants in Low-Density (10 and 20 pcf) Polyurethane Foam Blocks: Conical vs Cylindrical Implants. Int. J. Environ. Res. Public Health 2020, 17, 2617. [CrossRef] [PubMed]

6. Bornstein, M.M.; Halbritter, S.; Harnisch, H.; Weber, H.-P.; Buser, D. A Retrospective Analysis of Patients Referred for Implant Placement to a Specialty Clinic: Indications, Surgical Procedures, and Early Failures. Int. J. Oral Maxillofac. Implant. 2008, 23, 1109-1116.

7. Buck, D.W.; Dumanian, G.A. Bone Biology and Physiology: Part I. The Fundamentals. Plast. Reconstr. Surg. 2012, 129, 1314-1320. [CrossRef]

8. Majidinia, M.; Sadeghpour, A.; Yousefi, B. The Roles of Signaling Pathways in Bone Repair and Regeneration. J. Cell. Physiol. 2018, 233, 2937-2948. [CrossRef] [PubMed]

9. Danza, M.; Zollino, I.; Avantaggiato, A.; Lucchese, A.; Carinci, F. Distance between Implants Has a Potential Impact of Crestal Bone Resorption. Saudi Dent J 2011, 23, 129-133. [CrossRef]

10. Patianna, A.G.; Ballini, A.; Meneghello, M.; Cantore, S.; Inchingolo, A.M.; Dipalma, G.; Inchingolo, A.D.; Inchingolo, F.; Malcangi, G.; Lucchese, A.; et al. Comparison of Conventional Orthognathic Surgery and "Surgery-First" Protocol: A New Weapon against Time. J. Biol. Regul. Homeost. Agents 2019, 33, 59-67.

11. Rigo, L.; Viscioni, A.; Franco, M.; Lucchese, A.; Zollino, I.; Brunelli, G.; Carinci, F. Overdentures on Implants Placed in Bone Augmented with Fresh Frozen Bone. Minerva Stomatol. 2011, 60, 5-14. [CrossRef]

12. Rodriguez y Baena, R.; Pastorino, R.; Gherlone, E.F.; Perillo, L.; Lupi, S.M.; Lucchese, A. Histomorphometric Evaluation of Two Different Bone Substitutes in Sinus Augmentation Procedures: A Randomized Controlled Trial in Humans. Int. J. Oral Maxillofac. Implant. 2017, 32, 188-194. [CrossRef]

13. Piattelli, A.; Scarano, A.; Paolantonio, M. Bone Formation inside the Material Interstices of E-PTFE Membranes: A Light Microscopical and Histochemical Study in Man. Biomaterials 1996, 17, 1725-1731. [CrossRef]

14. Al-Hezaimi, K.; Iezzi, G.; Rudek, I.; Al-Daafas, A.; Al-Hamdan, K.; Al-Rasheed, A.; Javed, F.; Piattelli, A.; Wang, H.-L. Histomorphometric Analysis of Bone Regeneration Using a Dual Layer of Membranes (DPTFE Placed over Collagen) in Fresh Extraction Sites: A Canine Model. J. Oral Implant. 2015, 41, 188-195. [CrossRef]

15. Simion, M.; Trisi, P.; Piattelli, A. GBR with an E-PTFE Membrane Associated with DFDBA: Histologic and Histochemical Analysis in a Human Implant Retrieved after 4 Years of Loading. Int. J. Periodontics Restor. Dent. 1996, 16, 338-347. [CrossRef]

16. Simion, M.; Baldoni, M.; Rossi, P.; Zaffe, D. A Comparative Study of the Effectiveness of E-PTFE Membranes with and without Early Exposure during the Healing Period. Int. J. Periodontics Restor. Dent. 1994, 14, 166-180.

17. Bottino, M.C.; Thomas, V.; Schmidt, G.; Vohra, Y.K.; Chu, T.-M.G.; Kowolik, M.J.; Janowski, G.M. Recent Advances in the Development of GTR/GBR Membranes for Periodontal Regeneration-a Materials Perspective. Dent. Mater. 2012, 28, 703-721. [CrossRef]

18. Elgali, I.; Omar, O.; Dahlin, C.; Thomsen, P. Guided Bone Regeneration: Materials and Biological Mechanisms Revisited. Eur. J. Oral Sci. 2017, 125, 315-337. [CrossRef]

19. Oh, S.H.; Kim, J.H.; Kim, J.M.; Lee, J.H. Asymmetrically Porous PLGA/Pluronic F127 Membrane for Effective Guided Bone Regeneration. J. Biomater. Sci. Polym. Ed. 2006, 17, 1375-1387. [CrossRef]

20. Sam, G.; Pillai, B.R.M. Evolution of Barrier Membranes in Periodontal Regeneration-"Are the Third Generation Membranes Really Here?". J. Clin. Diagn. Res. 2014, 8, ZE14-ZE17. [CrossRef]

21. Diomede, F.; D’Aurora, M.; Gugliandolo, A.; Merciaro, I.; Orsini, T.; Gatta, V.; Piattelli, A.; Trubiani, O.; Mazzon, E. Biofunctionalized Scaffold in Bone Tissue Repair. Int. J. Mol. Sci. 2018, 19, 1022. [CrossRef]

22. Chierico, A.; Valentini, R.; Majzoub, Z.; Piattelli, A.; Scarano, A.; Okun, L.; Cordioli, G. Electrically Charged GTAM Membranes Stimulate Osteogenesis in Rabbit Calvarial Defects. Clin. Oral Implant. Res. 1999, 10, 415-424. [CrossRef]

23. Piattelli, A.; Piattelli, M.; Scarano, A. Simultaneous Demonstration of Alkaline and Acid Phosphatase Activity in Bone, at Bone-Implant Interfaces and at the Epiphyseal Growth Plate in Plastic-Embedded Undemineralized Tissues. Biomaterials 1997, 18, 545-549. [CrossRef]

24. Piattelli, A.; Scarano, A.; Coraggio, F.; Matarasso, S. Early Tissue Reactions to Polylactic Acid Resorbable Membranes: A Histological and Histochemical Study in Rabbit. Biomaterials 1998, 19, 889-896. [CrossRef]

25. Piattelli, A.; Scarano, A.; Mangano, C. Clinical and Histologic Aspects of Biphasic Calcium Phosphate Ceramic (BCP) Used in Connection with Implant Placement. Biomaterials 1996, 17, 1767-1770. [CrossRef]

26. Colangelo, P.; Piattelli, A.; Barrucci, S.; Trisi, P.; Formisano, G.; Caiazza, S. Bone Regeneration Guided by Resorbable Collagen Membranes in Rabbits: A Pilot Study. Implant Dent. 1993, 2, 101-105. [CrossRef] 
27. Cerrai, P.; Guerra, G.D.; Tricoli, M.; Krajewski, A.; Ravaglioli, A.; Martinetti, R.; Dolcini, L.; Fini, M.; Scarano, A.; Piattelli, A. Periodontal Membranes from Composites of Hydroxyapatite and Bioresorbable Block Copolymers. J. Mater. Sci. Mater. Med. 1999, 10, 677-682. [CrossRef]

28. Degidi, M.; Scarano, A.; Piattelli, A. Regeneration of the Alveolar Crest Using Titanium Micromesh with Autologous Bone and a Resorbable Membrane. J. Oral Implant. 2003, 29, 86-90. [CrossRef]

29. Assenza, B.; Piattelli, M.; Scarano, A.; Lezzi, G.; Petrone, G.; Piattelli, A. Localized Ridge Augmentation Using Titanium Micromesh. J. Oral Implant. 2001, 27, 287-292. [CrossRef]

30. Majzoub, Z.; Cordioli, G.; Aramouni, P.K.; Vigolo, P.; Piattelli, A. Guided Bone Regeneration Using Demineralized Laminar Bone Sheets versus GTAM Membranes in the Treatment of Implant-Associated Defects. A Clinical and Histological Study. Clin. Oral Implant. Res. 1999, 10, 406-414. [CrossRef]

31. Malchiodi, L.; Scarano, A.; Quaranta, M.; Piattelli, A. Rigid Fixation by Means of Titanium Mesh in Edentulous Ridge Expansion for Horizontal Ridge Augmentation in the Maxilla. Int. J. Oral Maxillofac. Implant. 1998, 13, 701-705.

32. Simion, M.; Jovanovic, S.A.; Trisi, P.; Scarano, A.; Piattelli, A. Vertical Ridge Augmentation around Dental Implants Using a Membrane Technique and Autogenous Bone or Allografts in Humans. Int. J. Periodontics Restor. Dent. 1998, 18, 8-23.

33. Simion, M.; Maglione, M.; Iamoni, F.; Scarano, A.; Piattelli, A.; Salvato, A. Bacterial Penetration through Resolut Resorbable Membrane in Vitro. An Histological and Scanning Electron Microscopic Study. Clin. Oral Implant. Res. 1997, 8, 23-31. [CrossRef] [PubMed]

34. Simion, M.; Scarano, A.; Gionso, L.; Piattelli, A. Guided Bone Regeneration Using Resorbable and Nonresorbable Membranes: A Comparative Histologic Study in Humans. Int. J. Oral Maxillofac. Implant. 1996, 11, 735-742.

35. Piattelli, M.; Scarano, A.; Piattelli, A. Vertical Ridge Augmentation Using a Resorbable Membrane: A Case Report. J. Periodontol. 1996, 67, 158-161. [CrossRef]

36. Donath, K.; Piattelli, A. Bone Tissue Reactions to Demineralized Freeze-Dried Bone in Conjunction with e-PTFE Barrier Membranes in Man. Eur. J. Oral Sci. 1996, 104, 96-101. [CrossRef]

37. Simion, M.; Trisi, P.; Piattelli, A. Vertical Ridge Augmentation Using a Membrane Technique Associated with Osseointegrated Implants. Int. J. Periodontics Restor. Dent. 1994, 14, 496-511.

38. Fontana, E.; Trisi, P.; Piattelli, A. Freeze-Dried Dura Mater for Guided Tissue Regeneration in Post-Extraction Dental Implants: A Clinical and Histologic Study. J. Periodontol. 1994, 65, 658-665. [CrossRef]

39. Simion, M.; Dahlin, C.; Trisi, P.; Piattelli, A. Qualitative and Quantitative Comparative Study on Different Filling Materials Used in Bone Tissue Regeneration: A Controlled Clinical Study. Int. J. Periodontics Restor. Dent. 1994, 14, 198-215. [CrossRef]

40. De Marco, P.; Zara, S.; De Colli, M.; Radunovic, M.; Lazović, V.; Ettorre, V.; Di Crescenzo, A.; Piattelli, A.; Cataldi, A.; Fontana, A. Graphene Oxide Improves the Biocompatibility of Collagen Membranes in an in Vitro Model of Human Primary Gingival Fibroblasts. Biomed. Mater. 2017, 12, 055005. [CrossRef]

41. Radunovic, M.; De Colli, M.; De Marco, P.; Di Nisio, C.; Fontana, A.; Piattelli, A.; Cataldi, A.; Zara, S. Graphene Oxide Enrichment of Collagen Membranes Improves DPSCs Differentiation and Controls Inflammation Occurrence. J. Biomed. Mater. Res. A 2017, 105, 2312-2320. [CrossRef] [PubMed]

42. Piattelli, A.; Scarano, A.; Piattelli, M.; Matarasso, S. Cellular Colonization and Bone Formation into Expanded Polytetrafluoroethylene Membranes: A Light Microscopical and Histochemical Time Course Study in the Rabbit. J. Periodontol. 1996, 67, 720-725. [CrossRef] [PubMed]

43. Piattelli, A.; Scarano, A.; Russo, P.; Matarasso, S. Evaluation of Guided Bone Regeneration in Rabbit Tibia Using Bioresorbable and Non-Resorbable Membranes. Biomaterials 1996, 17, 791-796. [CrossRef]

44. Abdulghani, S.; Mitchell, G.R. Biomaterials for In Situ Tissue Regeneration: A Review. Biomolecules 2019, 9 , 750. [CrossRef] [PubMed]

45. Albrektsson, T.; Berglundh, T.; Lindhe, J. Osseointegration: Historic Background and Current Concepts. Clin. Periodontol. Implant Dent. 2003, 4, 809-820.

46. Gehrke, S.A.; Tumedei, M.; Aramburú Júnior, J.; Treichel, T.L.E.; Kolerman, R.; Lepore, S.; Piattelli, A.; Iezzi, G. Histological and Histomorphometrical Evaluation of a New Implant Macrogeometry. A Sheep Study. Int. J. Environ. Res. Public Health 2020, 17, 3477. [CrossRef]

47. Tumedei, M.; Savadori, P.; Del Fabbro, M. Synthetic Blocks for Bone Regeneration: A Systematic Review and Meta-Analysis. Int. J. Mol. Sci. 2019, 20, 4221. [CrossRef] [PubMed]

48. Tumedei, M.; Piattelli, A.; Degidi, M.; Mangano, C.; Iezzi, G. A Narrative Review of the Histological and Histomorphometrical Evaluation of the Peri-Implant Bone in Loaded and Unloaded Dental Implants. A 30-Year Experience (1988-2018). Int. J. Environ. Res. Public Health 2020, 17, 2088. [CrossRef]

49. Tumedei, M.; Piattelli, A.; Degidi, M.; Mangano, C.; Iezzi, G. A 30-Year (1988-2018) Retrospective Microscopical Evaluation of Dental Implants Retrieved for Different Causes: A Narrative Review. Int. J. Periodontics Restor. Dent. 2020, 40, e211-e227. [CrossRef]

50. Atsuta, I.; Ayukawa, Y.; Kondo, R.; Oshiro, W.; Matsuura, Y.; Furuhashi, A.; Tsukiyama, Y.; Koyano, K. Soft Tissue Sealing around Dental Implants Based on Histological Interpretation. J. Prosthodont. Res. 2016, 60, 3-11. [CrossRef]

51. Bhatt, R.A.; Rozental, T.D. Bone Graft Substitutes. Hand. Clin. 2012, 28, 457-468. [CrossRef]

52. Gazdag, A.R.; Lane, J.M.; Glaser, D.; Forster, R.A. Alternatives to Autogenous Bone Graft: Efficacy and Indications. J. Am. Acad. Orthop. Surg. 1995, 3, 1-8. [CrossRef] 
53. Cornelini, R.; Scarano, A.; Piattelli, M.; Andreana, S.; Covani, U.; Quaranta, A.; Piattelli, A. Effect of Enamel Matrix Derivative (Emdogain) on Bone Defects in Rabbit Tibias. J. Oral Implantol. 2004, 30, 69-73. [CrossRef] [PubMed]

54. Simion, M.; Misitano, U.; Gionso, L.; Salvato, A. Treatment of Dehiscences and Fenestrations around Dental Implants Using Resorbable and Nonresorbable Membranes Associated with Bone Autografts: A Comparative Clinical Study. Int. J. Oral Maxillofac. Implant. 1997, 12, 159-167.

55. Lucchese, A.; Carinci, F.; Brunelli, G.; Monguzzi, R. Everstick ${ }^{\circledR}$ and Ribbond ${ }^{\circledR}$ fiber reinforced composites: Scanning Electron Microscope (SEM) comparative analysis. Eur. J. Inflamm. 2011, 9, 73-79.

56. Manuelli, M. A peaceful man. Prog. Orthod. 2012, 13, 1. [CrossRef] [PubMed] 